\title{
PENINGKATAN PENGETAHUAN DAN KETERAMPILAN IBU RUMAH TANGGA DALAM PENGOLAHAN TANAMAN OBAT KELUARGA (TOGA) SEBAGAI RAMUAN OBAT TRADISIONAL
}

\author{
Increased Knowledge and Skills of Housewives in Processing Family Medicinal Plants \\ (TOGA) as Traditional Medicines
}

\section{Nurul Qamariah* \\ Rezqi Handayani \\ Susi Novaryatiin \\ Universitas Muhammadiyah \\ Palangkaraya, Palangka Raya, \\ Kalimantan Tengah, Indonesia \\ *email: \\ gamariahnurulqamariah@gmail.com}

\section{Kata Kunci:}

Pengetahuan dan Keterampilan

Tanaman Obat Keluarga

Ramuan Tradisional

\section{Keywords:}

Knowledge and Skills

Family Medicinal Plants

Traditional Medicine Recipes

\begin{abstract}
Abstrak
Kegiatan pengabdian kepada masyarakat ini bertujuan untuk meningkatkan pengetahuan ibu rumah tangga tentang khasiat Tanaman Obat Keluarga (TOGA) secara ilmiah, meningkatkan pengetahuan dan keterampilan ibu rumah tangga untuk mengolah TOGA sebagai pilihan dalam terapi pengobatan. Kegiatan pengabdian ini dilaksanakan bertempat di Langgar Nurul Iman sekaligus sebagai tempat kegiatan rutin yasinan ibu-ibu rumah tangga di Jalan Sulawesi Gang Pelita Nomor 4I RT.004/RW.002 Kelurahan Langkai Kecamatan Pahandut Kota Palangka Raya Kalimantan Tengah. Melalui kegiatan ini, pengetahuan dan keterampilan ibu rumah tangga dalam pengolahan ramuan tradisional sebagai salah satu upaya dalam hal promotif, preventif dan kuratif dapat ditingkatkan.
\end{abstract}

\begin{abstract}
This community service activity aims to increase the knowledge of homemakers about the efficacy of the Family Medicinal Plants (TOGA) scientifically, improve the knowledge and skills of homemakers to process TOGA as an option in treatment therapy. Held at Langgar Nurul Iman as a place for routine activities for homemakers on Jalan Sulawesi Gang Pelita No.4I RT.004/RW.002 Langkai Village, Pahandut Subdistrict, Palangka Raya City, Central Kalimantan. Through this activity, the knowledge and skills of homemakers in processing traditional herbs as an effort to promote, preventive and curative can be improved.
\end{abstract}

\section{(c) (i) ()}

(C) 2019 The Authors. Published by Institute for Research and Community Services Universitas Muhammadiyah Palangkaraya. This is Open Access article under the CC-BY-SA License (http://creativecommons.org/licenses/bysa/4.0/). DOI: https://doi.org//0.33084/pengabdianmu.v4il.692.

\section{PENDAHULUAN}

Pemanfaatan pekarangan di pedesaan mempunyai banyak keuntungan terutama dalam meningkatan pendapatan keluarga misalnya sebagai warung hidup, lumbung hidup, apotek hidup, sehingga perlu dikembangkan secara intensif. Kenyataan saat ini, harga obat di pedesaan sangat tinggi, sering tidak tersedia, apotek sering tutup dan lebih sering lagi dokter tidak ada. Oleh karena itu penyediaan tanaman yang berfungsi sebagai obat herbal di pekarangan sangat membantu keluarga mengatasi masalah kesehatan. Tanaman obat sebenarnya memiliki fungsi ganda selain sebagai dekorasi halaman, tanaman obat berfungsi sebagai ramuan alami untuk mengobati berbagai penyakit yang seringkali timbul. Masyarakat di pedesaan belum memahami bahwa tanaman obat selain sangat berguna buat menyembuhkan berbagai penyakit, tanaman ini juga banyak dibutuhkan oleh industri obat-obatan, rumah sakit, dan perusahaan-perusahaan yang bergerak dibidang penjualan produk kesehatan. Beberapa ahli herbalis yakin bahwa pemanfaatan bahan-bahan yang bersifat alamiah lebih diterima oleh tubuh manusia dibandingkan dengan penggunaan bahan-bahan yang bersifat sintetik, walaupun mereka tahu betul bahwa khasiat pemanfaatan bahan-bahan yang alami cenderung relatif lambat. Kini, kecendrungan untuk kembali ke alam sudah bersifat global, ditandai dengan maraknya produk bahan alam baik dari dalam maupun dari luar negeri dengan berbagai macam label dan merk (Duaja et al., 20II). Saat ini pengembangan Tanaman Obat 
Keluarga (TOGA) masih banyak pada aspek pembudidayaan tanaman saja, belum banyak kelompok masyarakat yang mengetahui teknologi terapan dalam hal pengolahan pasca panen menjadi simplisia (bahan baku obat) maupun sediaan olahan pangan lainnya (Departemen Kesehatan Republik Indonesia, 1995). Aplikasi pengembangan kebun TOGA dengan metode penanaman yang tepat terbukti dapat meningkatkan produktivitas dari tanaman yang ditanam (Martono et al., 2017).

Mengubah kesadaran, pola pikir dan gaya hidup masyarakat memerlukan adanya sosialisasi. Pemerintah melalui kementerian kesehatan secara terus-menerus mensosialisasikan TOGA dan memotivasi masyarakat agar menanam tanaman obat-obatan. Bekerja sama dengan Dinas Kesehatan dan Pembina Kesejahteraan Keluarga (PKK) di masing-masing kabupaten di Indonesia, sosialisasi TOGA terus dilakukan baik melalui pelatihan hingga pengadaan lomba Desa atau Kota Pelaksana Terbaik Kegiatan Pemanfaatan Hasil TOGA hingga tingkat nasional. Tiga tahap keberhasilan sosialisasi pemanfaatan tanaman obat keluarga yang dilakukan oleh Tim Pergerak PKK, yakni persiapan, pelaksanaan serta evaluasi dan monitoring (Susanto, $2017)$.

Keberhasilan sosialisasi dapat meningkatkan minat masyarakat dalam memanfaatkan pengobatan tradisional. Hal itu dikarenakan masyarakat merasa pengobatan tradisional tersebut berasal dari bahan alami yang lebih murah dan bahan bakunya lebih mudah didapatkan seperti yang dilaporkan oleh Nursiyah (20I3). Selain itu, kearifan lokal masyarakat pada komunitas tertentu memungkinkan pemanfaatan obatobat tradisional (Situmorang \& Harianja, 2014). Menurut Katno dan Pramono (2016), beralihnya masyarakat kepada obat tradisional selain karena harganya lebih murah, bahan lebih mudah didapatkan bila ditanam sendiri, dan umumnya satu tanaman memiliki efek farmakologi lebih dari satu sehingga bermanfaat untuk pengobatan penyakit degeneratif dan metabolik. Efek dari pengobatan tradisonal yang dirasakan oleh masyarakat yaitu penyakit yang diderita sembuh dan cocok dengan obat yang diberikan oleh pengobatan tradisional yang disediakan oleh puskesmas. Semua jenis tanaman obat memang mengandung senyawa kimia alami, yang memiliki efek farmakologis dan aktivitas penting sampai berpotensi sebagai agen anti penyakit degeneratif (Rahmawati et al., 20I2). Pengobatan tradisional yang berasal dari tanaman merupakan manifestasi dari partisipasi aktif masyarakat dalam menyelesaikan problematika kesehatan dan telah diakui peranannya oleh berbagai bangsa dalam meningkatkan derajat kesehatan masyarakat. World Health Organization (WHO) merekomendasi penggunaan obat tradisional termasuk obat herbal dalam pemeliharaan kesehatan masyarakat, pencegahan dan pengobatan penyakit, terutama untuk kronis, penyakit degeneratif dan kanker (Setiawati et al, 20l6).

Pemanfaatan TOGA akan dirasakan manfaatnya bagi masyarakat terutama masyakarat golongan menengah ke bawah. Hal ini dikarenakan minimalnya biaya yang harus dikeluarkan oleh masyarakat untuk memanfaatkan TOGA dapat membantu masyarakat menengah ke bawah untuk menaikkan derajat kesehatan mereka. Tetapi masih banyak masyarakat yang belum memaksimalkan pemanfaatan TOGA sebagai salah satu terapi pengobatan keluarga. Minimnya fasilitas dan informasi bagi masyarakat terutama golonngan masyarakat menengah ke bawah menyebabkan pemanfaatan toga masih kurang dirasakan. Oleh karena itu pengabdian ini bertujuan untuk meningkatkan pengetahuan ibu rumah tangga tentang khasiat TOGA secara ilmiah, meningkatkan pengetahuan dan keterampilan ibu rumah tangga untuk mengolah TOGA sebagai pilihan dalam terapi pengobatan. 


\section{METODOLOGI}

Kegiatan pengabdian ini dilaksanakan di Langgar Nurul Iman sebagai tempat kegiatan rutin yasinan ibu-ibu rumah tangga di Jalan Sulawesi Gg. Pelita No.4I RT.004/RW.002 Kelurahan Langkai Kecamatan Pahandut Kota Palangka Raya Kalimantan Tengah. Metode yang digunakan dalam pengabdian ini adalah berupa penyuluhan dan prakek secara langsung pembuatan TOGA menjadi ramuan tradisional. Peserta pada kegiatan ini adalah kelompok masyarakat yang tidak produktif secara ekonomi yaitu 50 orang ibu-ibu rumah tangga RT.004/RW.002.

Pada kegiatan ini peserta diberikan informasi dan keterampilan dalam memanfaatkan TOGA sebagai ramuan tradisional. Peserta diberikan pelatihan cara meracik TOGA menjadi sediaan ramuan tradisional atau jamu. Sediaan ramuan tradisional yang dipraktekkan adalah ramuan tradisional yang mudah dibuat dan juga umum digunakan untuk meningkatkan kesehatan keluarga. Selain itu ramuan tradisional yang akan dipraktekkan berasal dari TOGA yang telah dibudidayakan pada tahap sebelumnya dan digunakan untuk mengatasi 5 penyakit yang telah yaitu demam, batuk, diare, gatal, dan pegal linu. Media yang digunakan pada kegiatan ini adalah peralatan dapur seperti kompor, panci, parutan, saringan teh, dan lain-lain. TOGA yang akan dijadikan ramuan tradisional diantaranya yaitu jeruk nipis, jahe, kunyit, kencur, dan bawang merah. Beberapa contoh ramuan yang akan dipraktekkan sebagai berikut: (Kementrian Kesehatan Republik Indonesia, 20I I)

I. Ramuan I untuk mengatasi Demam Bahan:
a. Jeruk nipis
I buah
b. Bawang Merah
3 biji
c. Minyak Kelapa
I sendok makan
d. Garam sedikit

Kalau tidak ada jeruk nipis dapat diganti dengan:
a. Asam Jawa matang
I sendok makan

Cara pembuatan:

\section{Cara I:}

Jeruk nipis diperas dan diambil airnya. Bawang merah dicuci, diparut dengan parutan yang dilapisi daun pisang. Kemudian ditambahkan perasan air jeruk nipis, garam sedikit dan minyak. Campurkan semua bahan tersebut dan diremas-remas hingga merata.

Cara II:

Bila memakai asam jawa, asam diremas-remas, kemudian dicampurkan dengan parutan bawang merah ditambah garam sedikit dan diberi minyak kelapa, diaduk hingga merata.

Cara Pemakaian:

Dikompreskan, atau ditempelkan pada ubun-ubun dan dahi, juga pada tengkuk dan punggung.

2. Ramuan II untuk mengatasi Batuk

Bahan:
a. Kencur
3 jari
b. Air
$3 / 4$ cangkir

Cara pembuatan:

Kencur dikupas dan diparut (parutannya dialasi dengan daun pisang). Tambahkan air $3 / 4$ cangkir, peras dan saring dengan kain bersih atau saringan teh.

Cara pemakaian:

Diminum 4-5 x sehari I sendok makan, oleh anak (lebih dari 12 tahun) dan dewasa.

3. Ramuan III untuk mengatasi Diare

Bahan:
a. Daun jambu biji (pucuk)
3 pucuk
b. Garam
sedikit

Cara pemakaian:

I) Daun jambu biji dikunyah dengan sedikit garam kemudian ditelan, sehari lakukan 2 kali.

2) Daun jambu biji ditumbuk, diberi air (yang telah dimasak) $1 / 2$ cangkir kemudian diperas, diminum sekaligus, sehari 2 kali.

4. Ramuan IV untuk mengatasi Gatal

Bahan:
a. Daun sirih
5-7 lembar
b. Air
I liter 
Cara pembuatan:

Daun sirih diremas dalam air lalu didiamkan $1 / 2$ jam hingga air menyusut.

Cara Pemakaian:

Gunakan air sirih sehabis mandi. Tanpa dikeringkan dengan handuk. Dan gunakan air sirih untuk ditepuktepukan ke daerah yang gatal.

5. Ramuan $\vee$ untuk mengatasi Pegal Linu Bahan:
a. Jahe
I jempol
b. Sereh
2 batang
c. Air
2 gelas
d. Gula merah
I sendok makan
e. Garam
seujung sendok

Cara pembuatan:

Jahe dibakar dan dimemarkan. Rebus jahe dan sereh dengan sedikit air. Setelah menyusut tambah sedikit gula merah. Diaduk dan didinginkan.

Cara pakai:

Minum dalam keadaan hangat pagi dan sore.

\section{HASIL DAN PEMBAHASAN}

Kegiatan yang dilakukan pada kegiatan penagbdian ini adalah sosialisasi dan praktek pengolahan TOGA sebagai ramuan tradisional. Kegiatan ini juga dilaksanakan pada mitra yang sama di Jalan Sulawesi Gg. Pelita No. 4I RT.004/RW.002 Kelurahan Langkai Kecamatan Pahandut Kota Palangka Raya Kalimantan Tengah. Kegiatan ini diikuti oleh 50 orang ibu rumah tangga yang tergabung dalam kelompok pengajian Langgar Nurul Iman. Kegiatan ini melibatkan 5 (lima) orang mahasiswa Program Studi D-III Farmasi UM Palangkaraya dan dilaksanakan pada Hari Jumat Tanggal 5 Oktober 2018 pada pukul 14.00-16.00 WIB.

Pada kegiatan ini metode yang digunakan adalah praktek langsung pengolahan TOGA menjadi ramuan tradisional. Ramuan tradisional yang di praktekkan adalah ramuan tradisional sesuai dengan resep yang ada di metode pelaksanaan. Ada 5 (lima) ramuan yang dipraktekkan secara langsung pada kegiatan ini yaitu ramuan untuk mengatasi demam yang teridiri dari jeruk nipis, bawang merah, minyak kelapa dan garam. Ramuan kedua yaitu ramuan yang digunakan untuk mengatasi batuk terdiri dari kencur dan air. Ramuan ketiga digunakan untuk mengatasi diare yang terdiri dari daun jambu biji dan sedikit garam. Ramuan keempat untuk mengatasi gatal pada kulit yang terdiri dari daun sirih dan air. Serta ramuan kelima adalah ramuan untuk mengatasi pegal linu yang terdiri dari jahe, sereh, air, gula merah dan garam. Untuk ramuan kesatu sampai keempat dipraktekkan secara langsung oleh tim dan mahasiswa didepan para mitra. Sedangkan untuk ramuan kelima tidak dipraktekkan secara langsung tetapi ramuan telah dibuat oleh mahasiswa kemudian dibagikan kepada mitra untuk di cicipi.

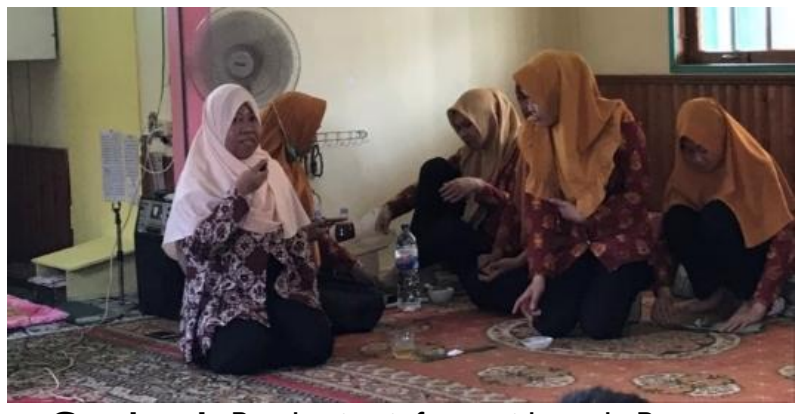

Gambar I. Pemberian informasi kepada Peserta Kegiatan

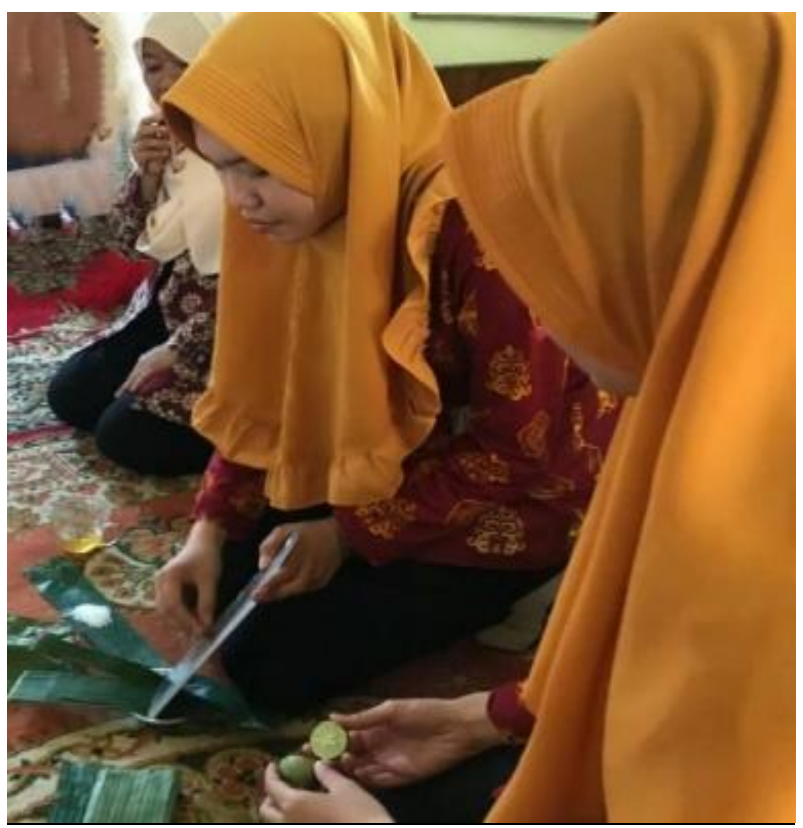

Gambar 2. Proses pembuatan ramuan tradisional 


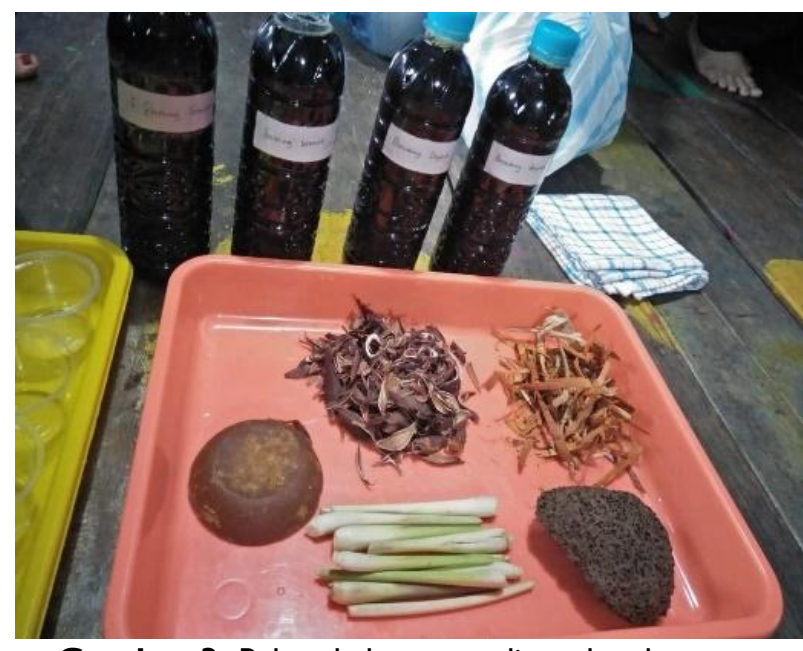

Gambar 3. Bahan-bahan yang digunakan beserta ramuan yang telah dihasilkan

Kegiatan inipun mendapatkan sambutan yang sangat baik dari para mitra. Terlihat dari kesediaan mitra untuk ikut langsung dalam praktek pembuatan ramuan tradisional. Mitra pun terlihat antusias untuk mencicipi ramuan tradisional yang telah dibuat oleh tim dan mahasiswa. Kegiatan ini ditutup dengan pemberian souvenir.

\section{KESIMPULAN}

Kegiatan pengabdian ini merupakan salah satu program rutin yang dilaksanakan oleh sivitas akademika Program Studi D3 Farmasi UM Palangkaraya sebagai salah satu tanggungjawab instuti pendidikan dalam membantu pemerintah untuk meningkatkan derajat kesehatan masyarakat. Dari kegiatan pengabdian ini dapat meningkatkan keterampilan ibu rumah tangga dalam pengolahan ramuan tradisional sebagai salah satu upaya dalam hal promotif, preventif dan kuratif.

\section{REFERENSI}

Departemen Kesehatan Republik Indonesia. 1995. Cara Pembuatan Obat Tradisional yang Baik. Jakarta: Departemen Kesehatan Republik Indonesia.

Duaja, M.D., Kartika, E., \& Mukhlis, F. 20I I. Peningkatan Kesehatan Masyarakat melalui Pemberdayaan Wanita dalam Pemanfaatan Pekarangan Dengan Tanaman Obat Keluarga (TOGA) di
Kecamatan Geragai. Jurnal Lembaga Pengabdian Kepada Masyarakat. 52:74-79.

Katno \& Pramono, S. 2016. Tingkat Manfaat dan Keamanan Tanaman Obat dan Obat Tradisional. Balai Penelitian Obat Tawangmangu. Yogyakarta: Fakultas Farmasi Universitas Gadjah Mada.

Kementerian Kesehatan Republik Indonesia. 201I. Pedoman Kader Pemanfaatan Tanaman Obat Keluarga Untuk Kesehatan Keluarga. Jakarta: Kementerian Kesehatan Republik Indonesia.

Martono, Y., Setiawan, A., \& Widodo, S. 2017. SABDA TOGA (Sarana Budidaya Tanaman Obat Keluarga) Untuk Daerah Perkotaan di RT 04 dan 06 RW 07 Kelurahan Tegalrejo Kota Salatiga. Berdikari: Jurnal Pengabdian Masyarakat Indonesia. I(I): I-5.

Nursiyah. 2013. Studi Deskriptif Tanaman Obat Tradisional yang Digunakan Orangtua untuk Kesehatan Anak Usia Dini di Gugus Melati Kecamatan Kalikajar Kabupaten Wonosobo. Skripsi. Semarang: Universitas Negeri Semarang.

Rahmawati, U., Suryani, E., \& Mukhlason, A. 2012. Pengembangan Repository Pengetahuan Berbasis Ontologi untuk Tanaman Obat Indonesia. Jurnal Teknik ITS. I(I): I-6.

Setiawati, A., Immanuel, H., ^ Utami, M.T. 2016. The inhibition of Typhonium flagelliforme Lodd. Blume leaf extract on COX-2 expression of WiDr colon cancer cells. Asian Pasific Journal of Tropical Biomedicine. 6(3):25 I-255.

Situmorang, R.O.P. \& Harianja, A. 20I4. Faktor-Faktor yang Mempengaruhi Kearifan Lokal Pemanfaatan Obat-Obatan Tradisional oleh Etnik Karo. In: Prosiding Ekspose Hasil Penelitian Tahun 20/4. Medan: Balai Penelitian Aek Nauli.

Susanto, A. 2017. Komunikasi Dalam Sosialisasi Tanaman Obat Keluarga (TOGA) di Kecamatan Margadana. Parapemikir : Jurnal Ilmiah Farmasi. 6(I): I I I-I I7. 